\title{
Length curves and volume functions for guadua bamboo (Guadua angustifolia Kunth) for the coffee region of Colombia
}

\author{
Juan Carlos Camargo García · Christoph Kleinn
}

Received: 27 September 2008/ Accepted: 2 June 2010/Published online: 30 July 2010

(c) Springer-Verlag 2010

\begin{abstract}
Three models for the prediction of bamboo culm length and two for culm volume were fitted from data of 303 guadua bamboo (Guadua angustifolia Kunth) culms. Data are from 101 temporary inventory plots systematically distributed over the coffee region of Colombia (inventory area about 1,029,525 ha). Linear and non-linear regression models were used, and the precision of the models was evaluated by cross-validation. The models were compared by studying the adjusted coefficient of determination, the bias, mean square error and Akaike's information criterion and by the $F$-test that compares predicted and observed values. For culm length, the best fit showed models that included predictor variables related to stand characteristics such as quadratic mean diameter and number of culms per ha. For culm volume prediction, the inclusion of culm length improved the model significantly. For the simple form factor model, precision of prediction was least. The models developed are useful in facilitating the estimation of stand characteristics that are relevant for the silvicultural management of Guadua stands and also for the assessment of their environmental services (such as carbon sequestration).
\end{abstract}

Communicated by D. Mandallaz.

J. C. Camargo García ( $\square)$

Faculty of Environmental Sciences, Technological

University of Pereira, La Julita, Pereira, Colombia

e-mail: jupipes@gmail.com

C. Kleinn

Section of Forest Inventory and Remote Sensing,

Georg-August-Universität Göttingen, Büsgenweg 5,

37077 Göttingen, Germany

e-mail: ckleinn@gwdg.de
Keywords Height curve - Regression models . Biomass - Carbon · Form factor .

Management of bamboo stands

\section{Introduction}

The bamboo species Guadua angustifolia Kunth has its natural habitat in Colombia, Ecuador, and Venezuela and was introduced to other countries in Central and South America, Europe and Asia (Londoño 2001). It is one of the 3 largest growing bamboo species (with diameters up to $18.5 \mathrm{~cm}$ ) and one of the economically most important in the world (Londoño et al. 2002). It has a wide distribution all over Colombia and covers an estimated area of 51,500 ha, of which about 46,250 ha are natural stands and 5.250 ha are plantations (Londoño 1998). Within the coffee region, where this study was done, a recent inventory yielded an estimated of about 40,000 ha of Guadua stands (Kleinn and Morales 2006), which are highly fragmented and follow mainly the courses of rivers and creeks as "gallery bamboo forest". For numerous rural communities, this bamboo resource plays an important role for their livelihoods as raw material for manifold construction purposes and also for handicraft. For many families, Guadua products are the main source of income (Riaño et al. 2002).

While research into the use of Guadua culms and in particular into the technological properties of the Guadua wood is relatively well established (Londoño et al. 2002; Camargo 2006), this is less so for the management of the Guadua resource. This management has been following largely traditional approaches, where the experiences in the communities were passed to the following generations, and this refers practically exclusively to natural Guadua stands. It is only for a relatively short period of time that systematic 
scientific approaches are being pursued as to learn, for example, about the growth and regeneration pattern of Guadua bamboo, about the potential impact of harvesting schemes and/or site characteristics on wood quality, about the establishment of artificial Guadua plantations, and, summarizing the above, about optimizing the production systems.

One of the basics of the management of a renewable natural resource is "to get the numbers right", that is to develop approaches for the procurement of the information that is required for informed management decisions; these information requirements embrace both biophysical features such as area, density, volume etc. and use-related features such as the harvesting schemes and utilization purposes. For Guadua bamboo in Colombia, actually, there is quite some scattered information, but still the basic mensuration relationships have not been comprehensively worked out and transparently presented. This input is not only required for immediate practical applications (when, for example, marketing and selling the resource "Guadua culms") but also to foster research towards optimal management systems for Guadua stands.

Diameter at breast height (dbh) and total height are variables that are commonly observed in forest inventories. They are excellent indicators for growing stock, site quality and other stand characteristics important for management and planning. Although the biological growth patterns of bamboo and trees are very different, the basic issues that we need to address in a bamboo inventory are not so different: we are in the first place interested in the number of culms per hectare, in the diameter distribution and also in culm length and volume information. For commercially utilized trees height and length are usually very close to identical. For bamboo, however, which is highly bended in the upper sections, height and length are considerably different (Camargo 2006). For bamboo, the variable of interest is culm length, because it is directly related to the eventual commercial product.

The height of the diameter measurement must also be clearly defined for Guadua bamboo. In forestry, it is common to use a fixed height for the default diameter measurement (breast height $=1.3 \mathrm{~m}$ as an international standard applied in many regions). This concept, however, is not immediately suitable for bamboo mensuration because diameter varies considerably with proximity to the internodes. Therefore, it is sensible to define here the reference diameter in the middle between those internodes where the conventional breast height is $1.3 \mathrm{~m}$. It means that the diameter is taken at slightly varying heights but all close to $1.3 \mathrm{~m}$.

For bamboo species, regression models to predict culms length from diameter are rarely used (for example (FU 2001). A very simple model predicts culm length $(L)$ in metres from the perimeter $(C)$ in centimetres at breast height times a constant $K$, which is to be determined empirically for the specific areas of interest. Among the published constants for $G$. angustifolia are $K=0.56$ (Arbeláez 1996) and $K=0.5837$ (Cruz 1994).

Culm volume is one of the central attributes when analysing and comparing stand productivity (García 2004; Camargo et al. 2007). There are not many studies on volume functions for bamboo (Camargo 2006, Reid et al. 2004). In this context, it is also important to stress the differences between the assessment of the development of tree stands and bamboo stands. For bamboo, the development of the diameter of the individual culm is of lesser relevance as bamboo has no vascular cambium and consequently no secondary diameter growth: each culm emerges with a fixed diameter (Judziewicz et al. 1999), which it maintains over its entire life period. Culm height and length are an important factor of culm development. After having reached the maximum elongation, however, which may be as soon as after 6 months, it takes much more time for the wood to reach maturity (Liese 1995). It is one of the most important and difficult aspects of the management of Guadua bamboo to determine the earliest point in time of full maturity of the culms. Culms that are harvested early have much worse physical-mechanical properties and are much less durable.

In addition, many bamboos species (Guadua included) have hollow internodes with a lumen and a wall thickness that varies considerably from species to species (Judziewicz et al. 1999). The variable wood volume as a productivity measure for bamboo stands requires, therefore, a very clear definition (FU 2001).

For volume prediction in forest inventories, diameter is usually the most relevant predictor variable (Sharma et al. 2002). However, most of the bamboo stands are relatively homogenous with respect to diameter, culm length and culm volume. Therefore, integration of length as a second predictor should be straightforward. We define here two concepts of volume: the culm volume is the gross volume of the entire culm, including the hollow sections; the woody volume (=net volume) may then be estimated by a conversion factor or a more elaborated statistical model.

The objective of this study is to analyse and evaluate different regression models for length and volume prediction of $G$. angustifolia culms in the coffee region of Colombia, which is one information component that is required for the sustainable management of this resource.

\section{Materials and methods}

Study area and sampling

The study sites are located in the coffee region of Colombia, which has a total area of 1.029.524 ha and 
elevations between 900 and 2000 m.a.s.l. This vertical range corresponds to the elevation range of $G$. angustifolia there. Mean annual temperature is between $20^{\circ}$ and $27^{\circ} \mathrm{C}$ and precipitation between 950 and 2,500 $\mathrm{mm}$ per year with a bimodal distribution. Most of the soils are Andisols from volcanic ashes, are slightly acid and have good physical properties such as structural stability, high effective depth, low apparent density and high porosity (García 2004).

The sample culms came from an inventory that had been carried out in a research project on Guadua bamboo (Kleinn and Morales 2006). Systematic two-stage sampling was applied. In the first stage, the entire study area was subdivided into primary units of $10 \mathrm{~km} \times 10 \mathrm{~km}$. Out of these primary units, a number of 103 were randomly selected. In the centre of each selected primary unit, a square plot of $3 \mathrm{~km} \times 3 \mathrm{~km}$ was established on aerial photographs. In these aerial photo sample plots, all G. angustifolia stands were mapped. A number of 16 aerial photo sample plots were selected for field sampling, and a total of 101 field plots of $10 \mathrm{~m} \times 10 \mathrm{~m}$ were randomly selected within these mapped $G$. angustifolia stands.

In each $10 \mathrm{~m} \times 10 \mathrm{~m}$ field plot, diameter at breast height (at middle of the internode at breast height) of all culms was tape measured. Culm length was measured at 3 culms that were randomly selected on the plot and cut. These culms were then also used to calculate apparent and net volume by the Smalian equation (Dieguez et al. 2003), where "apparent volume" includes all hollow parts of the culm, and "net volume" refers to the volume of the woody parts of the stem only. Culm diameter and wall thickness were measured for that purpose at 3 sections of the culm: at the height of the lowest internode, in the middle of culm and at the height of the last internode. Per-hectare stand variables were extrapolated from the sample plot data such as basal area (based on the diameter measurement), number of culms and the quadratic mean diameter.

Regression models

A large number of height curves and volume functions have been reported in the forest mensuration literature, mostly species- and/or region-specific. For this particular study, for the length models, we consider those most commonly used in forest mensuration and those that were used for other bamboo species as Phyllostachys pubescens for predicting height ( $\mathrm{Fu} 2001)$.

The following notation is used throughout this paper: $h=$ total length of the culm $[\mathrm{m}] ; h_{\mathrm{int}}=$ height at lowest internode $[\mathrm{cm}] ; d=$ diameter at internode at breast height $[\mathrm{cm}] ; d_{\mathrm{g}}=$ quadratic mean diameter of the stand $[\mathrm{cm}]$; $d_{\text {int }}=$ diameter at the height of the lowest-internode $[\mathrm{cm}]$; $N=$ number of culms per hectare; $t=$ mean culm wall thickness, $e=$ base of natural logarithm and $b_{\mathrm{i}}=$ estimated regression coefficients.

A total of 15 models for culm length and 7 for culm volume were fitted and validated (Tables 1 and 2). It is important to remark that most of the models analysed for both variables have been applied by different authors exclusively for predicting tree height (Pearl and Reed 1920; Winsor 1932; Richards 1959; Curtis 1967; Yang et al. 1978; Schreuder et al. 1979; Bates and Watts 1980; Schnute 1981; Sibbesen 1981; Wykoff et al. 1982; Buford 1986; Larson 1986; Ratkowsky and Reedy 1986; Larsen and Hann 1987; Zeide 1989; Ratkowsky 1990; Huang et al. 1992; Prodan et al. 1997) and tree volume Sharma et al. (2002) and Prodan et al. 1997.
Table 1 Functions used to model culm length from culm diameter

* Modification of the original model omitting the predictor $N$ and thus reducing the number of independent variables

** Modification of the original model omitting the predictor mean value of the maximum and minimum stand height, which were not available in this inventory

\begin{tabular}{|c|c|}
\hline Model reference or name & Expression \\
\hline 1. Linear & $h=b_{0}+b_{1} d$ \\
\hline 2. Potential (Prodan et al. 1997) & $h=1.3+b_{0} \cdot d^{b_{1}}$ \\
\hline 3. Wykoff et al. (1982) & $h=1.3+\left(\frac{b_{0} \cdot d}{b_{1}+d}\right)$ \\
\hline 4. Bates and Watts (1980) & $h=1.3+b_{0} \cdot\left(1-e^{-b_{1} \cdot d}\right)$ \\
\hline 5. Buford (1986) & $h=1.3+10^{b_{0}} \cdot d^{b_{1}}$ \\
\hline 6. Larson (1986) & $h=1.3+\left(\frac{b_{0} \cdot d}{d+1}\right)+b_{1} \cdot d$ \\
\hline 7. Larsen and Hann (1987) & $h=1.3+e^{\left(b_{0}+b_{1} \cdot d^{b_{2}}\right)}$ \\
\hline 8. Pearl and Reed (1920) & $h=1.3+\frac{b_{0}}{\left(1+b_{1} \cdot e^{-b_{2} \cdot d}\right)}$ \\
\hline 9. Richards (1959) & $h=1.3+b_{0} \cdot\left(1-e^{-b_{1} \cdot d}\right)^{b_{2}}$ \\
\hline 10. Yang et al. (1978) & $h=1.3+b_{0} \cdot\left(1-e^{-b_{1} \cdot d^{b_{2}}}\right)$ \\
\hline 11. Prodan et al. (1997) & $h=1.3+e^{b_{0}} \cdot d^{b_{1}}$ \\
\hline 12. Richards (1959) & $h=1.3+b_{0} \cdot\left(1-e^{-b_{1} \cdot d^{b_{2}}}\right)^{b 3}$ \\
\hline 13. Cox I Mod. 1* (López et al. 2003) & $h=e^{\left(b_{0}+b_{1} \cdot \ln \left(d_{g}\right)+b_{3} \cdot \sqrt{d}\right)}$ \\
\hline 14. Cox II Mod. 2** (López et al. 2003) & $h=b_{0}+b_{2} \cdot\left(d_{g}^{0.95}\right)+b_{3} \cdot e^{(-0.08)}+b_{5} \cdot\left(d^{3}\right) \cdot e^{(-0.08 \cdot d)}$ \\
\hline 15. Cox I. (López et al. 2003) & $h=e^{\left(b_{0}+b_{1} \cdot \ln \left(d_{g}\right)+b_{2} \cdot \ln N+b_{3} \cdot \sqrt{d}\right)}$ \\
\hline
\end{tabular}


Table 2 Functions used to model culm volume from culm diameter and culm length

\begin{tabular}{ll}
\hline Model reference or name & Expression \\
\hline 1. Berkhout (Allometric) (Dieguez et al. 2003) & $V=b_{0} \cdot d^{b_{1}}$ \\
2. Allometric I & $V=b_{0} \cdot d^{b_{1}} \cdot d_{\text {int }}^{b_{2}}$ \\
3. Allometric II & $V=b_{0} \cdot d^{b_{1}} \cdot h_{\text {int }}^{b_{2}}$ \\
4. Schumacher-Hall (Dieguez et al. 2003) & $V=b_{0} \cdot d^{b_{1}} \cdot h^{b_{2}}$ \\
5. Allometric III & $V=b_{0} \cdot d^{b_{1}} \cdot t^{b_{2}}$ \\
6. Taper (Sharma et al. 2002) & $V=b_{0} \cdot d^{b_{1}} \cdot h^{\left(3-b_{1}\right)}$ \\
7. Linear & $V=b_{0}+b_{1} \cdot d$ \\
\hline
\end{tabular}

Statistical analysis

The majority of the models described in Tables 1 and 2 are non-linear regression models. Analysis was done with PROC NLIN (SAS 1999) of SAS/STAT ${ }^{\circledR}$ using the GaussNewton algorithm (Hartley 1961). The initial values for the iterative procedure were obtained by previously linearizing the model equations and fitting it to the data by ordinary least squares.

The estimated models were compared by graphical and numerical analysis of the residuals and by four statistics that describe model fit and quality: the bias $B$, the mean square error $M S E$, the coefficient of determination and the adjusted coefficient of variation, $R^{2}$ and $R_{\text {adj }}^{2}$, respectively, and Akaike's information criterion differences $\left(\Delta_{j}\right)$.

A cross-validation was carried out for each model, estimating the regression coefficients from a random subset of the data and taking the remaining data to test the performance of the resulting model. This performance was evaluated from the prediction residuals by the same statistics that were used to assess model fit (see preceding paragraph). In addition, $\mathrm{MEF}_{\text {adj }}^{2}$ was calculated, a measure of model precision (López et al. 2003).

To check for bias, the linear model (Hui and Gadow 1999) was fitted between the observed (and assumed true) value and the predicted value; a bias is likely to be absent with a given error probability if the estimated slope coefficient does not differ significantly from 1 and the estimated intercept not from 0 . Values of culm apparent and net volume estimated with the form factor were compared with the regression models by bias and mean square error.

\section{Results}

Models for culm length

Regression models 13 and 15 performed best for culm length prediction. The adjusted coefficient of determination $\left(R_{\mathrm{adj}}^{2}\right)$ is around 0.5 , and the bias is small. Best precision (MSE) is achieved with the modified model 13 (López et al. 2003) and also Akaike's criterion and $\mathrm{MEF}_{\text {adj }}^{2}$ indicate its best performance. This model also resulted slightly better than model 15. Cox I (López et al. 2003) that showed similar values (Tables 3 and 4). The modified model 13 Cox I Mod 1 (López et al. 2003) includes the stand variable $d_{\mathrm{g}}$, and the good results obtained with this model are consistent with those obtained for Pinus radiata in Chile (Cox 1994) and in Spain (López et al. 2003). However, no references were found for applying these models to Guadua or other bamboo species.

Table 3 Regression statistics for the culm length models

\begin{tabular}{|c|c|c|c|c|c|c|c|c|c|c|}
\hline \multirow[t]{2}{*}{ Model } & \multirow[t]{2}{*}{ Variables } & \multicolumn{5}{|c|}{ Fitting phase } & \multicolumn{4}{|c|}{ Estimated coefficients } \\
\hline & & $R^{2}$ & $R_{\mathrm{adj}}^{2}$ & Bias & MSE & $\Delta_{j}$ & $b_{0}$ & $b_{1}$ & $b_{2}$ & $b_{3}$ \\
\hline 1 & $d$ & 0.4620 & 0.4602 & 0.0000 & 7.0173 & 17.2 & 6.753 & 1.24 & & \\
\hline 2 & $d$ & 0.4615 & 0.4597 & 0.0031 & 7.0236 & 17.5 & 3.412 & 0.72 & & \\
\hline 3 & $d$ & 0.4600 & 0.4582 & 0.0036 & 7.0430 & 18.3 & 71.41 & 29.82 & & \\
\hline 4 & $d$ & 0.4596 & 0.4578 & -0.0020 & 7.0492 & 18.6 & 43.41 & 0.053 & & \\
\hline 5 & $d$ & 0.4615 & 0.4597 & 0.0013 & 7.0236 & 17.5 & 0.53 & 0.72 & & \\
\hline 6 & $d$ & 0.4620 & 0.4602 & -0.0001 & 7.0178 & 17.2 & 6.49 & 1.19 & & \\
\hline 7 & $d$ & 0.4607 & 0.4583 & 0.0024 & 7.0338 & 19.9 & 7.31 & -6.47 & -0.166 & \\
\hline 8 & $d$ & 0.4621 & 0.4596 & -0.0041 & 7.0399 & 19.2 & 39.81 & 4.37 & 0.127 & \\
\hline 9 & $d$ & 0.4614 & 0.4590 & 0.0000 & 7.0251 & 19.5 & 156.3 & 0.006 & 0.743 & \\
\hline 10 & $d$ & 0.4614 & 0.4590 & 0.0043 & 7.0248 & 19.5 & 299.3 & 0.011 & 0.745 & \\
\hline 11 & $d$ & 0.4615 & 0.4603 & 0.0034 & 7.0236 & 17.5 & 1.23 & 0.720 & & \\
\hline 12 & $d$ & 0.4610 & 0.4574 & 0.0001 & 7.0303 & 21.7 & 88.81 & 0.050 & 0.745 & 1.131 \\
\hline 13 & $d, d_{g}$ & 0.4950 & 0.4928 & -0.0035 & 6.6083 & 0.00 & 1.388 & 0.272 & 0.297 & 1.388 \\
\hline 14 & $d, d_{g}$ & 0.4948 & 0.4897 & -1.8184 & 6.6350 & 130.4 & 24.78 & 0.797 & -27.24 & 0.0009 \\
\hline 15 & $d, d_{g}, N$ & 0.4963 & 0.4912 & -0.0068 & 6.6142 & 1.2 & 1.248 & 0.283 & 0.013 & 0.297 \\
\hline
\end{tabular}


Table 4 Statistics of crossvalidation for culm length models

\begin{tabular}{lllllrlc}
\hline Model & Variables & \multicolumn{5}{l}{ Cross-validation } & \\
\cline { 3 - 7 } & & MFE $_{\text {adj }}$ & $F$ & $P>F$ & \multicolumn{1}{l}{ Bias } & MSE & $\Delta_{j}$ \\
\hline 1 & $d$ & 0.5450 & 257.9 & $<0.0001$ & -0.0124 & 7.062 & 6.18 \\
2 & $d$ & 0.5456 & 257.2 & $<0.0001$ & 0.0017 & 7.068 & 6.37 \\
3 & $d$ & 0.5472 & 255.6 & $<0.0001$ & 0.0043 & 7.087 & 6.83 \\
4 & $d$ & 0.5478 & 255.0 & $<0.0001$ & 0.0688 & 7.093 & 7.02 \\
5 & $d$ & 0.5456 & 257.2 & $<0.0001$ & 0.0032 & 7.068 & 7.34 \\
6 & $d$ & 0.5450 & 257.9 & $<0.0001$ & 0.0005 & 7.0623 & 6.21 \\
7 & $d$ & 0.5499 & 256.6 & $<0.0001$ & 0.0014 & 7.078 & 8.56 \\
8 & $d$ & 0.5488 & 257.8 & $<0.0001$ & 0.0078 & 7.108 & 8.22 \\
9 & $d$ & 0.5495 & 257.0 & $<0.0001$ & -0.0029 & 7.07 & 8.45 \\
10 & $d$ & 0.5495 & 257.3 & $<0.0001$ & 0.0679 & 7.069 & 8.46 \\
11 & $d$ & 0.5456 & 257.3 & $<0.0001$ & 0.0016 & 7.068 & 6.372 \\
12 & $d$ & 0.5513 & 256.9 & $<0.0001$ & -0.0021 & 7.072 & 10.46 \\
13 & $d, d_{g}$ & 0.5212 & 288.6 & $<0.0001$ & 0.0016 & 6.652 & 0.0000 \\
14 & $d, d_{g}$ & 0.6251 & 254.3 & $<0.0001$ & -0.8838 & 6.599 & 28.28 \\
15 & $d, d_{g}, N$ & 0.5249 & 288.5 & $<0.0001$ & 0.0060 & 6.674 & 2.024 \\
\hline
\end{tabular}

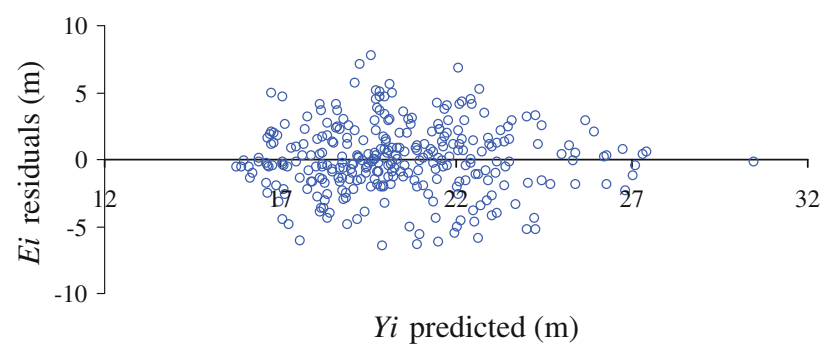

Fig. 1 Residuals versus predicted culm length for model 13. Cox I Mod. 1 (López et al. 2003)

Graphical analysis of bias and mean square error against diameter classes were done for all models. The plot of residuals versus predicted culm length showed that there was no reason to reject the hypotheses of normality, homogeneity of variance and independence of residuals (Fig. 1) for model 13. Cox I Mod 1 (López et al. 2003). The comparison of observed and predicted culm length values exhibits relatively wide variation, but a major systematic deviation is not observed (see Fig. 2).

Bias and mean square error were calculated and plotted against diameter. Additionally, other models are also depicted so as to demonstrate the contrast to the best model 13 Cox I Mod. 1 (López et al. 2003). In general, the models show a trend towards underestimation in particular for the higher diameter classes; however, model 14 Cox II Mod. 2 (López et al. 2003) is always upwards biased (Figs. 3 and 4).

Models for culm volume

The culm volume models showed an overall good performance where, in general, apparent culm is more precisely

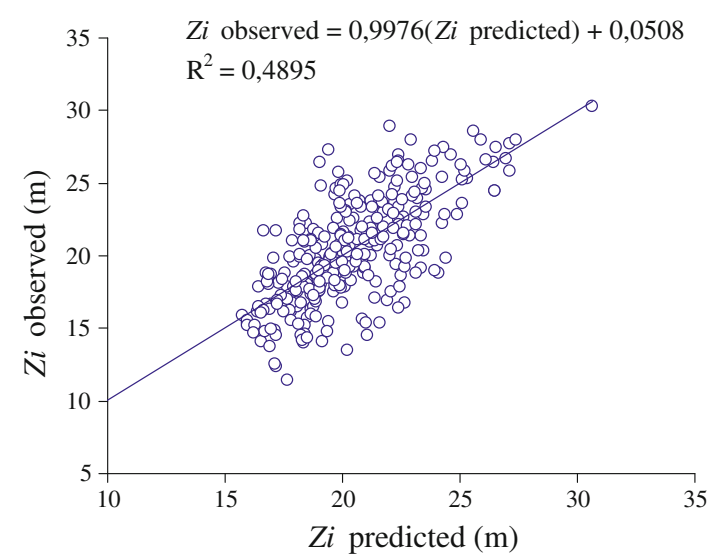

Fig. 2 Observed versus predicted culm length for model 13. Cox I Mod. 1 (López et al. 2003)

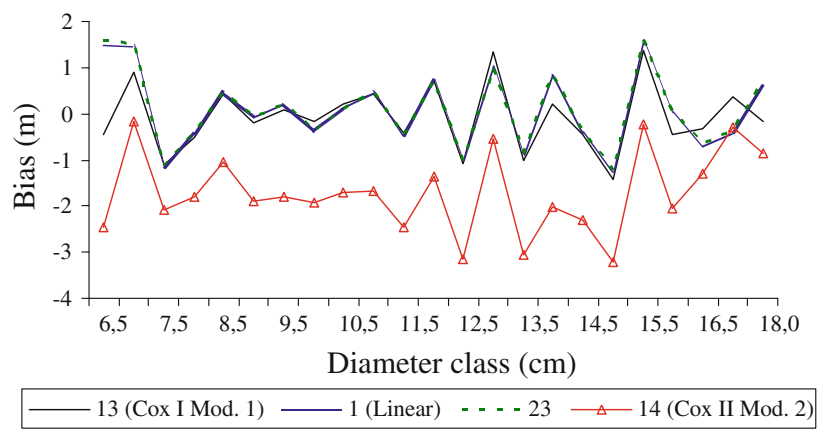

Fig. 3 Deviations between true and predicted value (bias) per diameter class for models 13 Cox I Mod. 1 (López et al. 2003), 1 (Linear), 6. (Larson 1986) and 14 Cox II Mod. (López et al. 2003) 


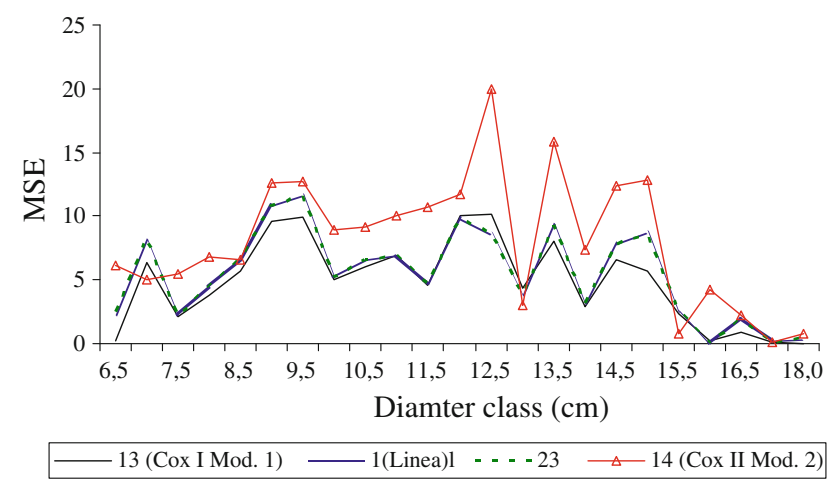

Fig. 4 Mean square error (MSE) per diameter class for models 13 Cox I Mod. 1 (López et al. 2003), 1 (Linear), 6. (Larson 1986) and 14 Cox II Mod. (López et al. 2003)

predicted than net volume; inclusion of culm length as predictor variable improves the models considerably (Tables 5 and 6).

Model 4 Schumacher-Hall (Dieguez et al. 2003) for apparent volume and model 5 (allometric III) for net volume perform best here. The plot of residuals versus predicted culm volume gives no reason to reject the hypotheses of normality, homogeneity of variance and independence of residuals (Figs. 5 and 6).

The regression and the plot of observed versus predicted culm volumes (Figs. 7 and 8) show a relatively strong relationship with moderate variability only and no indications for systematic deviations.

To analyse the performance of the best models, bias and mean square error were plotted against diameter classes. For comparison, model 2 (allometric I) was included in this analysis. The precision of prediction in terms of absolute values tends to decrease for higher diameter classes for all statistics depicted in Figs. 9, 10, 11, 12.

The relationship between culm apparent volume and culm net volume is based on culm features such as diameter and culm length, which are used to calculate both variables from culms cut. Hence, this relationship may be used to estimate culm net volume from culm apparent volume. A simple model results as

$V_{\text {net }}=0.001059+0.2840 . V_{\text {app }}$

$\left(R_{\text {adj }}^{2}=0.9398 \mathrm{MSE}=1.5824 \mathrm{E}-05\right)$.

\section{Discussion}

Models for culm length

Model 13 Cox I Mod. 1 (López et al. 2003), which includes two independent variables, gives an overall better performance than the others. This may be due in part to the inclusion of the stand-characterizing variable $d_{g}$ that may reflect stand conditions. It is likely that inclusion of further independent variables would help increasing model fit and precision of prediction.

This is also seen with models 15 Cox I (López et al. 2003) and 14 Cox II Mod. 2 (López et al. 2003), despite their larger bias. However, including more variables means increasing the measurement effort at the same time. Model 13 Cox I Mod. 1 (López et al. 2003) offers a balance between model accuracy and measurement effort, because the value of $d_{g}$ is readily obtained from $d$ and $N$.

The basic regression models used are those that are successfully also used for trees in forest inventories.

Table 5 Regression statistics for the volume models

\begin{tabular}{|c|c|c|c|c|c|c|c|c|c|c|}
\hline \multirow[t]{2}{*}{ Volume } & \multirow[t]{2}{*}{ Model } & \multirow[t]{2}{*}{ Variables } & \multicolumn{5}{|c|}{ Fitting phase } & \multicolumn{3}{|c|}{ Estimated coefficients } \\
\hline & & & $R^{2}$ & $R_{\text {adj }}^{2}$ & Bias & MSE & $\Delta j$ & $b_{0}$ & $b_{1}$ & $b_{2}$ \\
\hline \multirow{7}{*}{$V_{\text {app }}$} & 1 & $d$ & 0.803 & 0.802 & 0.00010351 & 0.00061 & -30.77 & 0.0004 & 2.317 & \\
\hline & 2 & $d, d_{\text {int }}$ & 0.808 & 0.807 & $-3.2853 \mathrm{E}-05$ & 0.00059 & -37.29 & 0.0004 & 1.790 & 0.567 \\
\hline & 3 & $d, h_{\mathrm{int}}$ & 0.803 & 0.802 & $9.5881 \mathrm{E}-05$ & 0.00061 & -29.11 & 0.0004 & 2.332 & -0.022 \\
\hline & 4 & $d, h$ & 0.939 & 0.938 & -0.00067466 & 0.00019 & -382.36 & 0.0001 & 1.341 & 1.417 \\
\hline & 5 & $d, t$ & 0.818 & 0.816 & $-9.6842 \mathrm{E}-05$ & 0.00056 & -52.20 & 0.0008 & 1.978 & 0.415 \\
\hline & 6 & $d, h$ & 0.924 & 0.924 & 0.00487653 & 0.00023 & -311.52 & $3.4 \mathrm{E}-6$ & 1.679 & \\
\hline & 7 & $d$ & 0.782 & 0.781 & $2.5218 \mathrm{E}-16$ & 0.00067 & 0.00 & -0.1582 & 0.025 & \\
\hline \multirow[t]{7}{*}{$V_{\text {net }}$} & 1 & $d$ & 0.788 & 0.787 & 0.00014528 & 0.00006 & -634.45 & 0.0001 & 2.316 & \\
\hline & 2 & $d, d_{\mathrm{int}}$ & 0.797 & 0.795 & $7.2358 \mathrm{E}-05$ & 0.00005 & -643.91 & 0.0001 & 1.686 & 0.677 \\
\hline & 3 & $d, h_{\mathrm{int}}$ & 0.789 & 0.788 & 0.00011382 & 0.00006 & -633.07 & 0.0001 & 2.337 & -0.029 \\
\hline & 4 & $d, h$ & 0.905 & 0.904 & 0.01861536 & 0.00003 & 0.0000 & 0.0000 & 1.422 & 1.307 \\
\hline & 5 & $d, t$ & 0.891 & 0.890 & $-1.4114 \mathrm{E}-05$ & 0.00003 & -832.93 & 0.0006 & 1.418 & 1.092 \\
\hline & 6 & $d, h$ & 0.894 & 0.894 & 0.00083431 & 0.00003 & -844.49 & $9.97 \mathrm{E}-06$ & 1.6480 & \\
\hline & 7 & $d$ & 0.761 & 0.760 & $7.2183 \mathrm{E}-17$ & 0.00006 & -596.56 & -0.0452 & 0.007 & \\
\hline
\end{tabular}


Table 6 Statistics for cross-validation of volume models

\begin{tabular}{|c|c|c|c|c|c|c|c|c|}
\hline \multirow[t]{2}{*}{ Volume } & \multirow[t]{2}{*}{ Model } & \multirow[t]{2}{*}{ Variables } & \multicolumn{6}{|c|}{ Cross-validation } \\
\hline & & & MFEadj & $F$ & $P>F$ & Bias & MSE & $\Delta_{j}$ \\
\hline \multirow[t]{7}{*}{$V_{\text {app }}$} & 1 & $d$ & 0.20 & 1219.0 & $<0.0001$ & $-4.57 \mathrm{E}-06$ & 0.00061 & -16.52 \\
\hline & 2 & $d, d_{\mathrm{int}}$ & 0.19 & 1252.8 & $<0.0001$ & $-9.26 \mathrm{E}-05$ & 0.00059 & -17.81 \\
\hline & 3 & $d, h_{\mathrm{int}}$ & 0.21 & 1172.2 & $<0.0001$ & $-9.32 \mathrm{E}-05$ & 0.00060 & -9.63 \\
\hline & 4 & $d, h$ & 0.06 & 4557.5 & $<0.0001$ & -0.000271 & 0.00019 & -190.46 \\
\hline & 5 & $d, t$ & 0.19 & 1318.9 & $<0.0001$ & $3.93 \mathrm{E}-05$ & 0.00057 & -24.16 \\
\hline & 6 & $d, h$ & 0.07 & 4192.7 & $<0.0001$ & 0.002511 & 0.00024 & -163.05 \\
\hline & 7 & $d$ & 0.22 & 1062.4 & $<0.0001$ & $2.35 \mathrm{E}-05$ & 0.00067 & 0.0000 \\
\hline \multirow[t]{7}{*}{$V_{\text {net }}$} & 1 & $d$ & 0.20 & 1116.7 & $<0.0001$ & $2.62 \mathrm{E}-05$ & 0.00006 & -315.77 \\
\hline & 2 & $d, d_{\mathrm{int}}$ & 0.20 & 1132.9 & $<0.0001$ & 0.000106 & 0.00005 & -314.66 \\
\hline & 3 & $d, d_{\mathrm{int}}$ & 0.22 & 1038.2 & $<0.0001$ & 0.000119 & 0.00006 & -303.82 \\
\hline & 4 & $d, h$ & 1.65 & 1071.4 & $<0.0001$ & 0.01835 & 0.00003 & 0.0000 \\
\hline & 5 & $d, t$ & 0.11 & 2429.7 & $<0.0001$ & $1.64 \mathrm{E}-05$ & 0.00003 & -410.40 \\
\hline & 6 & $d, h$ & 0.10 & 2829.2 & $<0.0001$ & 0.001008 & 0.00294 & -421.61 \\
\hline & 7 & $d$ & 0.24 & 939.4 & $<0.0001$ & $7.41 \mathrm{E}-06$ & 0.00006 & -294.42 \\
\hline
\end{tabular}

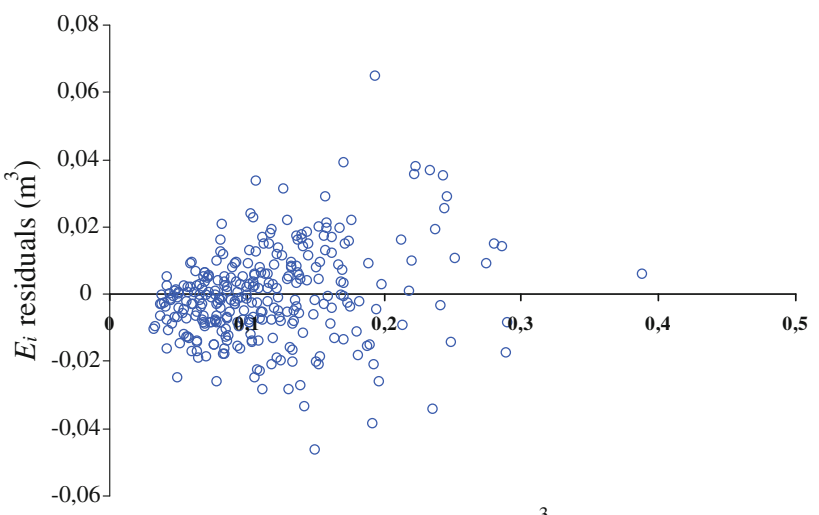

$Y_{i}$ Observed $\left(\mathrm{m}^{3}\right)$

Fig. 5 Residuals versus predicted apparent volume for model 4 Schumacher-Hall (Dieguez et al. 2003)

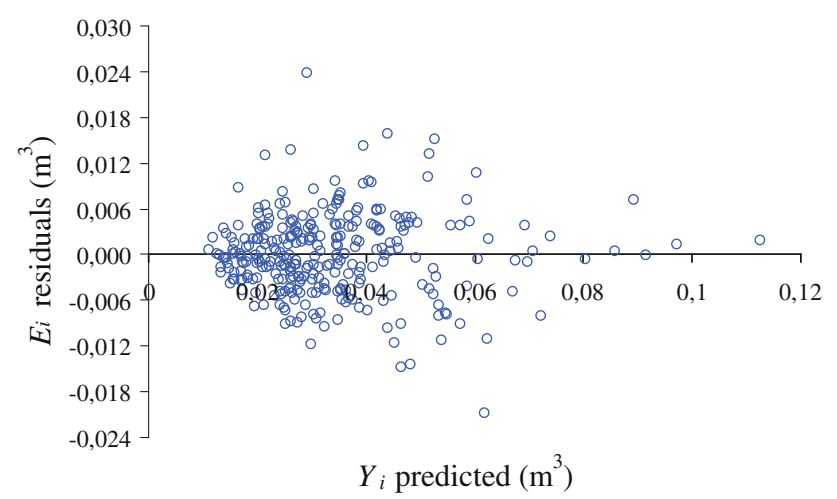

Fig. 6 Residuals versus predicted net volume for model 5 allometric III

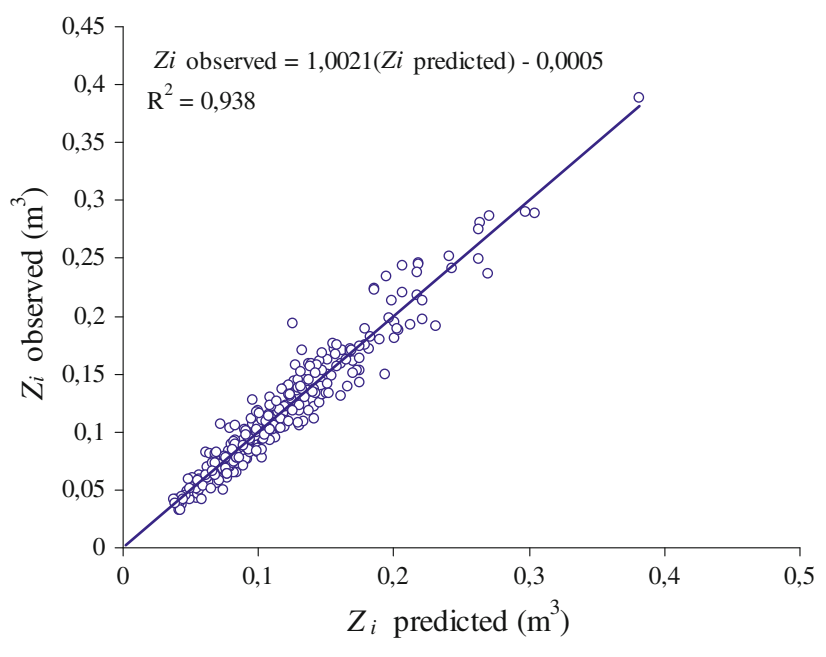

Fig. 7 Observed culm apparent volume values versus predicted culm apparent volume model 4 Schumacher-Hall (Dieguez et al. 2003)

However, growth pattern of Guadua and of trees is fundamentally different: One single individual of G. angustifolia has usually numerous culms. One encounters even stands which practically consist of one single individual. Consequently, culm length might depend not only on diameter but also on stand and site variables (including those which are influenced and codetermined by the management of the stand). The inclusion of stand variables is also used for trees (Dieguez et al. 2003; Prodan et al. 1997), and the inclusion of stand variables into the models helped improving the predictions (López et al. 2003).

For bamboo species, a-though relatively weak-relationship between total number of culms in a stand and culm 


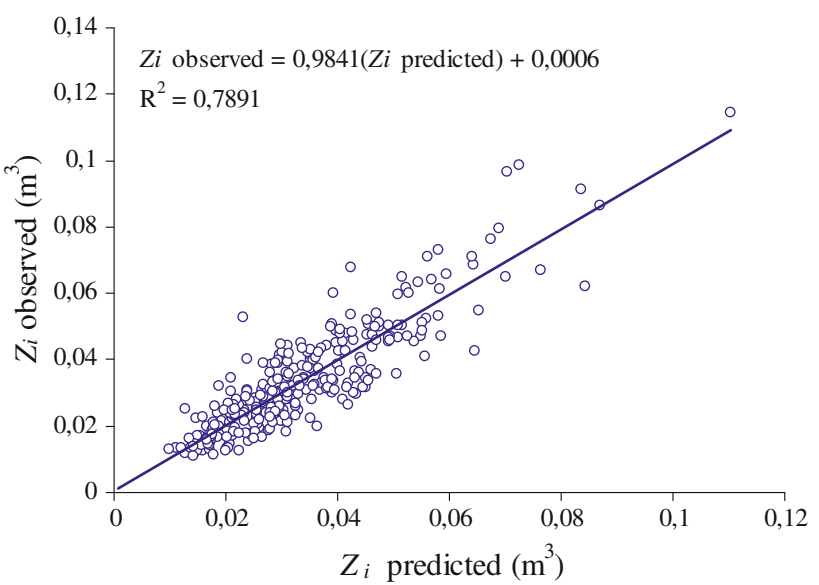

Fig. 8 Observed versus predicted culm net volume for model 5 allometric III

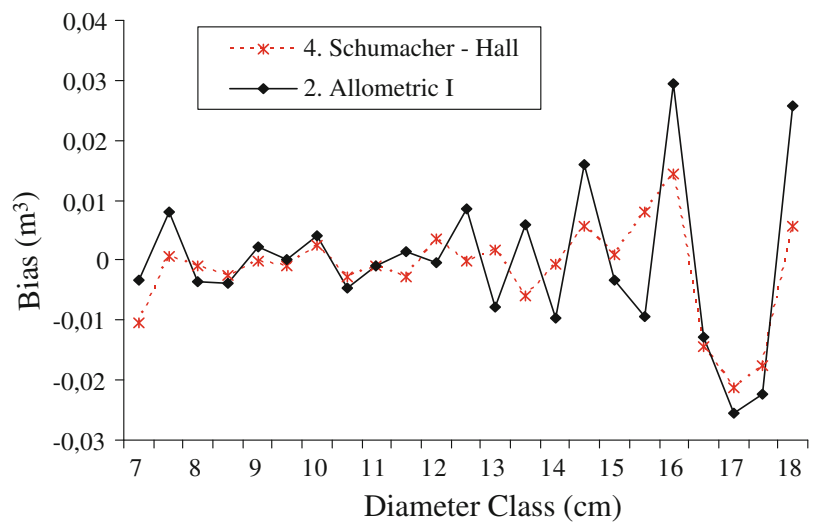

Fig. 9 Deviations between true and predicted value (bias) of culm apparent volume per diameter class for the model that showed best performance, model 4 Schumacher-Hall (Dieguez et al. 2003) contrasted with model 2 (allometric I)

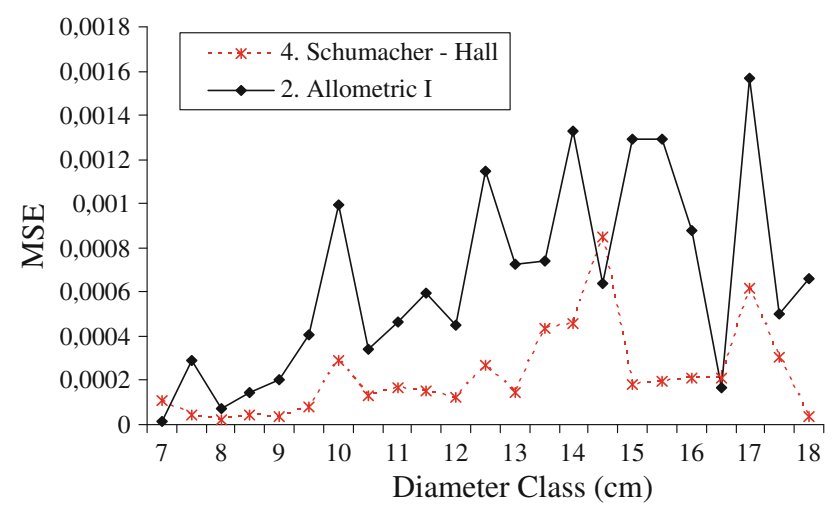

Fig. 10 Mean square error (MSE) of predicted culm apparent volume per diameter class for the best model 4 Schumacher-Hall (Dieguez et al. 2003) and the much poorer performing model 2 (allometric I)

length has been described (Camargo 2006; Fu 2001). This relationship may be among the reasons for the better performance of models that include stand variables.

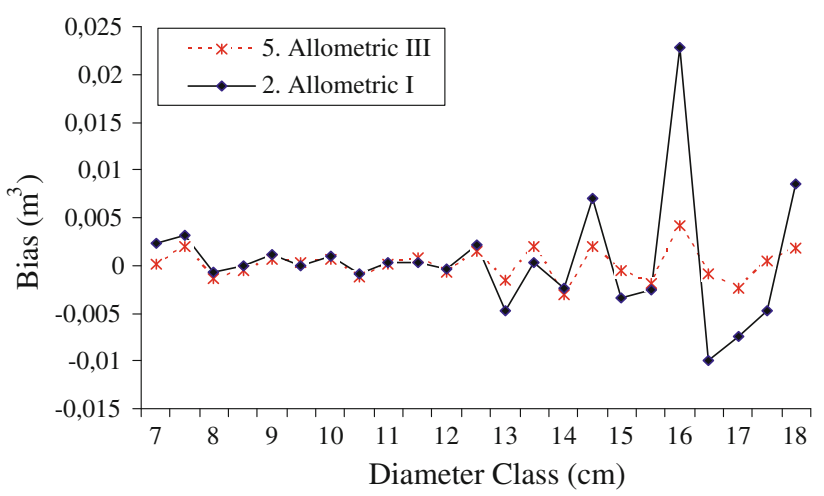

Fig. 11 Differences between true and predicted value (bias) of culm net volume per diameter class for the best model 5 (allometric III) and the much poorer performing model 2 (allometric I)

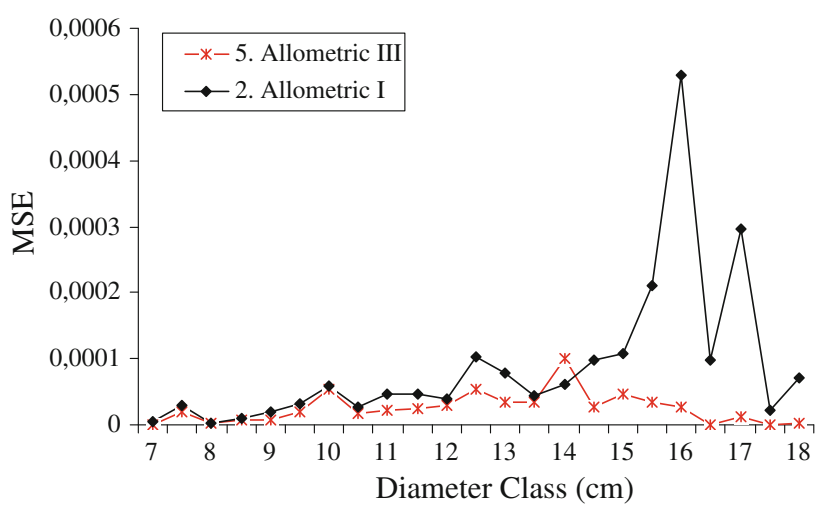

Fig. 12 Mean square error (MSE) of predicted culm net volume per diameter class for the best model 5 (allometric III) and the much poorer performing model 2 (allometric I)

Models for culm volume

For obvious geometric reasons, both culm diameter and culm length are important factors determining culm volume, and the precision of models that included both variables resulted higher. However, also model 2 (Allometric I) with the predictor variables diameter at internode at breast height $(d)$ and diameter at lowest-internode height $\left(d_{\text {int }}\right)$ shows an acceptable level of precision and may be used for volume estimation. Model 2 is recommendable in situations where culm length and/or wall thickness were not observed.

Volume models fitted with only the diameter as predictor variable yield good predictions if the relationship between culm diameter and culm height is strong (Prodan et al. 1997), and this holds mainly for application in smaller area inventories. Wall thickness is an important variable for culm net volume, and it is included in the best model 5 (allometric III). Absolute wall thickness decreases as does the diameter from the base to the top, and this tendency may contribute to explain why models to estimate apparent volume can also be used for estimating net volume. 


\section{Conclusions}

Regression models commonly used in forest inventory proved flexible enough also for Guadua bamboo culm length and culm volume prediction. Our data are from the coffee region of Colombia, and the model performance found here holds for that region in the first place. Transfer and application to other regions would require careful validation. All data were from natural Guadua stands, which is the by far most common stand type in the study region. Guadua plantations established recently (about eight years ago) where the bamboo clumps have not yet reached their maximum growth did not appear suitable for models that are predominantly used to estimate the harvestable resource.

The models resulting from this study will serve as a useful tool for those who manage Guadua stands in the coffee region of Colombia. The methods applied in this study will be helpful also for bamboo inventories in other regions and do also support the implementation of large area studies such as the special study on bamboo resources envisaged in the Global Forest Resource Assessment FRA2010 of FAO (Lobovikov et al. 2007). An important immediate application of these models will be to bring more light into the overall biomass and carbon production and dynamics of Guadua stands.

Acknowledgments The authors wish to thank the Program INCO of the European Union for financing the Project Guadua Bamboo "Research for sustainable management and markets of Bamboo in Colombia" (contract No. ICA4-2000-10209); COLCIENCIAS for financing the Project "Populational dynamics of Guadua angustifolia under different site and silvicultural management conditions in the Coffee Growing Region of Colombia"; and to the Technological University of Pereira (Faculty of Environmental Sciences) for financing and supporting the development of this research in the framework of the Project Guadua Bamboo; Project GTZ-UTP for their economic and logistical support. We also extend our thanks to the owners of the farms for allowing us to work in their properties.

\section{References}

Arbeláez AC (1996) Relación entre los caracteres morfológicos del tallo de la guadua (Guadua angustifolia Kunth). Project report. Medellín: Universidad Nacional de Colombia, p 21

Bates DM, Watts DG (1980) Relative curvature measures of nonlinearity. J R Stat Soc B 42:1-16

Buford MA (1986) Height-diameter relationship at age 15 in loblolly pine seed sources. For Sci 32:812-818

Camargo JC (2006) Growth and productivity of the bamboo species Guadua angustifolia Kunth in the coffee region of Colombia. $\mathrm{PhD}$ thesis. Göttingen, Universität. Cuvillier Verlag, Göttingen, Germany, p 205

Camargo JC, Dossman MA, Cardona G, García JH, Arias LM (2007) Zonificación detallada del recurso guadua en el Eje Cafetero, Tolima y Valle del Cauca: Municipios piloto del proyecto Manejo Sostenible de Bosques en Colombia (Guía metodológica y resultados). Ministerio de Ambiente Vivienda y Desarrollo
Territorial, Universidad Tecnológica de Pereira, Corporaciones Autónomas Regionales del Tolima, Quindío, Valle del Cauca y Risaralda. Pereira, Colombia, p 143

Cox F (1994) Modelos parametrizados de altura Informe de convenio de investigación interempresas. INFORA, Santiago, p 28

Cruz H (1994) La Guadua nuestro bambú. Corporación autónoma regional del Quindío (CRQ) y Centro Nacional para el Estudio del Bambú y la Guadua. Armenia, Quindío. Colombia, p 293

Curtis RO (1967) Height-diameter and height-diameter-age equations for second-growth Douglas-fir. For Sci 13:365-375

Dieguez U, Barrio M, Castedo F, Ruiz AD, Alvarez MF, Alvarez JG (2003) Dendrometría. Mundi Prensa Ed. Madrid, España, p 321

Fu JH (2001) The competitive strength of Moso Bamboo (Phyllostachys pubescens Mazel ex H. de Lehaie) in the natural mixed evergreen broad-leaved Forest of the Fujian Province, China. $\mathrm{PhD}$ thesis. Göttingen, Universität. Cuvillier Verlag, Göttingen, Germany, p 150

García JH (2004) Definición de áreas óptimas de calidad de guadua (Guadua angustifolia kunth), orientada a satisfacer las necesidades del mercado. Thesis MSc. Facultad de Ingeniería Industrial, Universidad Tecnológica de Pereira, p 110

Hartley HO (1961) The modified Gauss-Newton method for the fitting of nonlinear regression functions by least squares. Technometrics 3:269-280. doi:10.2307/1266117

Huang S, Titus S, Wiens D (1992) Comparison of nonlinear height diameter functions for major Alberta tree species. Can J For Res 22:1297-1304

Hui G, Gadow KV (1999) Modelling forest development. Kluwer Academic Publishers, Goettingen, Germany, p 213

Judziewicz EJ, Clark LG, Londoño X, Stern M (1999) American bamboos. Smithsonian Institution press, Washington, p 392

Kleinn C, Morales D (2006) An inventory of Guadua (Guadua angustifolia) bamboo in the coffee region of Colombia. Eur J For Res 125(4):361-368. doi:10.1007/s10342-006-0129-3

Larsen DR, Hann DW (1987) Height-diameter equations for seventeen tree species in southwest Oregon. Oreg State Univ For Res Lab 46:16

Larson BC (1986) Development and growth of even-aged stands of Douglas-fir and grand fir. Can J For Res 16:367-372. doi: $10.1139 / \times 86-063$

Liese W (1995) Anatomy and utilization of bamboos. Eur Bamboo Soc J (May). p 5-12

Lobovikov M, Pauldel S, Plazza M, Ren H, Wu J (2007) World bamboo resources. A thematic study prepared in the framework of the global forest resources assessment 2005. Non wood forest products 18. International network for bamboo and rattan (INBAR) and food and agriculture organization of the united nations (FAO). Rome, p 73

Londoño X (1998) Evaluation of bamboo resources in Latin America. Final report of project No. 96-8300-01-4 for international network for bamboo and rattan (INBAR), pp 19-35

Londoño X (2001) La guadua: un bambú importante de América. Procana 56:10-14

Londoño X, Camayo G, Riaño N, López Y (2002) Characterization of the anatomy of Guadua angustifolia (Poaceae: Bambusoideae) culms. Bamboo Sci Cult The J Am Bamboo Soc 16(1):18-31

López CA, Gorgojo J, Castedo F, Rojo A, Rodríguez R, Alvarez JG, Sánchez F (2003) A height-diameter model for Pinus radiata D. Don in Galicia (Northwest Spain). Ann For Sci 60:237-245. doi: 10.1051/forest:2003015

Pearl R, Reed LJ (1920) On the rate of growth of the population of United States since 1790 and its mathematical representation. Proc Natl Acad Sci USA 6(6):275-288. doi:10.1073/pnas.6.6.275

Prodan M, Peters R, Cox F, Real P (1997) Mensura forestal. GTZ. IICA. Series de investigación y educación en desarrollo sostenible, p 560 
Ratkowsky DA (1990) Handbook of nonlinear regression. Marcel Dekker Inc, New York, p 480

Ratkowsky DA, Reedy TJ (1986) Choosing near-linear parameters in the four-parameter logistic model for radioligand and related assays. Biometrics 42:575-582. doi:10.2307/2531207

Reid S, Díaz IA, Armesto JJ, Willson MF (2004) Importance of native bamboo for understory birds in Chilean temperate forest. Auk 121(2):515-525. doi:10.1642/0004-8038(2004)121[0515:IONBFU] 2.0.CO; 2

Riaño N, Londoño X, Gómez J (2002) Plant growth and biomass distribution on Guadua angustifolia Kunth in relation to ageing in the Valle del Cauca-Colombia. Bamboo Science and Culture. J Am Bamboo Soc 16(1):43-51

Richards FJ (1959) A flexible growth function for empirical use. J Exp Bot 10:290-300. doi:10.1093/jxb/10.2.290

SAS INSTITUTE INC (1999) SAS/STATTM user's guide, release 8.0 edition. Cary, USA

Schnute J (1981) A versatile growth model with statistically stable parameters. Can J Fish Aquat Sci 38:1128-1140. doi:10.1139/ f81-153
Schreuder HT, Hafley WL, Bennett FA (1979) Yield prediction for un thinned natural slash pine stands. For Sci 25:25-30

Sharma M, Oderwald RG, Amateis RL (2002) A consistent system of equation for tree and stand volume. For Ecol Manage 165: 183-191. doi:10.1016/S0378-1127(01)00616-8

Sibbesen E (1981) Some new equations to describe phosphate sorption by soils. J Soil Sci 32:67-74. doi:10.1111/j.1365-2389. 1981.tb01686.x

Winsor SB (1932) The gompertz curve as a growth curve. Proc Natl Acad Sci USA 18:1-8. doi:10.1073/pnas.18.1.1

Wykoff WR, Crookston NL, Stage AR (1982) User's guide to the stand prognosis model. USDA Forrest service generation technical report. INT-133. Department of agriculture, forest service, intermountain forest and range experiment station

Yang RC, Kozak A, Smith JHG (1978) The potential of weibull-type functions as a flexible growth curves. Can J For Res 8:424-431. doi:10.1139/x78-062

Zeide B (1989) Accuracy of equations describing diameter growth. Can J For Res 19:1283-1286 